\title{
Impact of Two Intense Dust Storms on Aerosol Characteristics and Radiative Forcing over Patiala, Northwestern India
}

\author{
Deepti Sharma, ${ }^{1}$ Darshan Singh, ${ }^{1}$ and D. G. Kaskaoutis ${ }^{2}$ \\ ${ }^{1}$ Physics Department, Punjabi University, Patiala 147002, India \\ ${ }^{2}$ Research and Technology Development Centre, Sharda University, Greater Noida 201306, India
}

Correspondence should be addressed to Darshan Singh, dsjphy@yahoo.com

Received 9 November 2011; Revised 1 March 2012; Accepted 20 March 2012

Academic Editor: Aristides Bartzokas

Copyright ( 2012 Deepti Sharma et al. This is an open access article distributed under the Creative Commons Attribution License, which permits unrestricted use, distribution, and reproduction in any medium, provided the original work is properly cited.

\begin{abstract}
Impact of dust storms on the aerosol characteristics and radiative forcing over Patiala, northwestern India has been studied during April-June of 2010 using satellite observations and ground-based measurements. Six dust events (DE) have been identified during the study period with average values of Aqua-MODIS AOD 550 and Microtops-II AOD A00 $_{5}$ over Patiala as $1.00 \pm 0.51$ and $0.84 \pm 0.41$, respectively while Aura-OMI AI exhibits high values ranging from 2.01 to 6.74 . The Ångström coefficients $\alpha_{380-870}$ and $\beta$ range from 0.12 to 0.31 and 0.95 to 1.40 , respectively. The measured spectral AODs, the OPAC-derived aerosol properties and the surface albedo obtained from MODIS were used as main inputs in SBDART model for the calculation of aerosol radiative forcing (ARF) over Patiala. The ARF at surface (SRF) and top of atmosphere (TOA) ranges from $\sim-50$ to $-100 \mathrm{Wm}^{-2}$ and from -10 to $-25 \mathrm{Wm}^{-2}$, respectively during the maximum of dust storms. The radiative forcing efficiency was found to be $-66 \mathrm{Wm}^{-2} \mathrm{AOD}^{-1}$ at $\mathrm{SRF}$ and $-14 \mathrm{Wm}^{-2} \mathrm{AOD}^{-1}$ at TOA. High values of ARF in the atmosphere (ATM), ranging between $\sim+40 \mathrm{Wm}^{-2}$ and $+80.0 \mathrm{Wm}^{-2}$ during the DE days, might have significant effect on the warming of the lower and middle atmosphere and, hence, on climate over northwestern India.
\end{abstract}

\section{Introduction}

Atmospheric aerosols exert climate forcing by perturbing the Earth's radiative balance directly by extinction of the solar and Earth radiation and, indirectly, by acting as cloud condensation nuclei (CCN) affecting the cloud albedo, cloud lifetime, precipitation rate, and hydrological cycle $[1,2]$. Mineral dust aerosols constitute a major fraction of atmospheric aerosols over the globe and have an important role in regulating the global climate $[3,4]$. However, considerable uncertainties exist in quantifying the impact of mineral dust on global radiative forcing mainly due to heterogeneous mixture of optical, physical, and chemical properties of dust aerosols $[5,6]$, in addition to their spatial, vertical, and temporal distributions [7]. The optical properties of dust aerosols vary spatially and temporally due to regional variations of soil characteristics and mixing of dust with other aerosol species, such as black carbon (BC) $[8,9]$.

Sand and dust storms are widespread natural phenomena that transport dust aerosols to long distances from the source region and represent an important process of landatmosphere interaction $[10,11]$. Apart from perturbing the radiation-energy balance of the Earth-atmosphere system, dust storms also affect atmospheric heating and stability [12], chemical and biological ecosystems [13], as well as ambient air quality and human health [14]. Satellite observations from multiple platforms [15-17] have shown that the global sources of atmospheric dust are the arid and semiarid regions of the planet dumping the mineral dust in to the atmosphere through long-range transport lifted by strong winds.

Dust storms are common in the northwestern part of the Indian subcontinent covered by Thar Desert, which is a primary source of dust storms in south Asia [17-20]. The dust outflow over the region exhibits a marked seasonality with higher frequency and intensity during dry premonsoon season (April-June), when dust covers the main part of the Indo-Gangetic Plains (IGP), driven by the westerly southwesterly winds [21-23]. As a consequence, dust strongly affects the aerosol characteristics over IGP as it is mixed with 


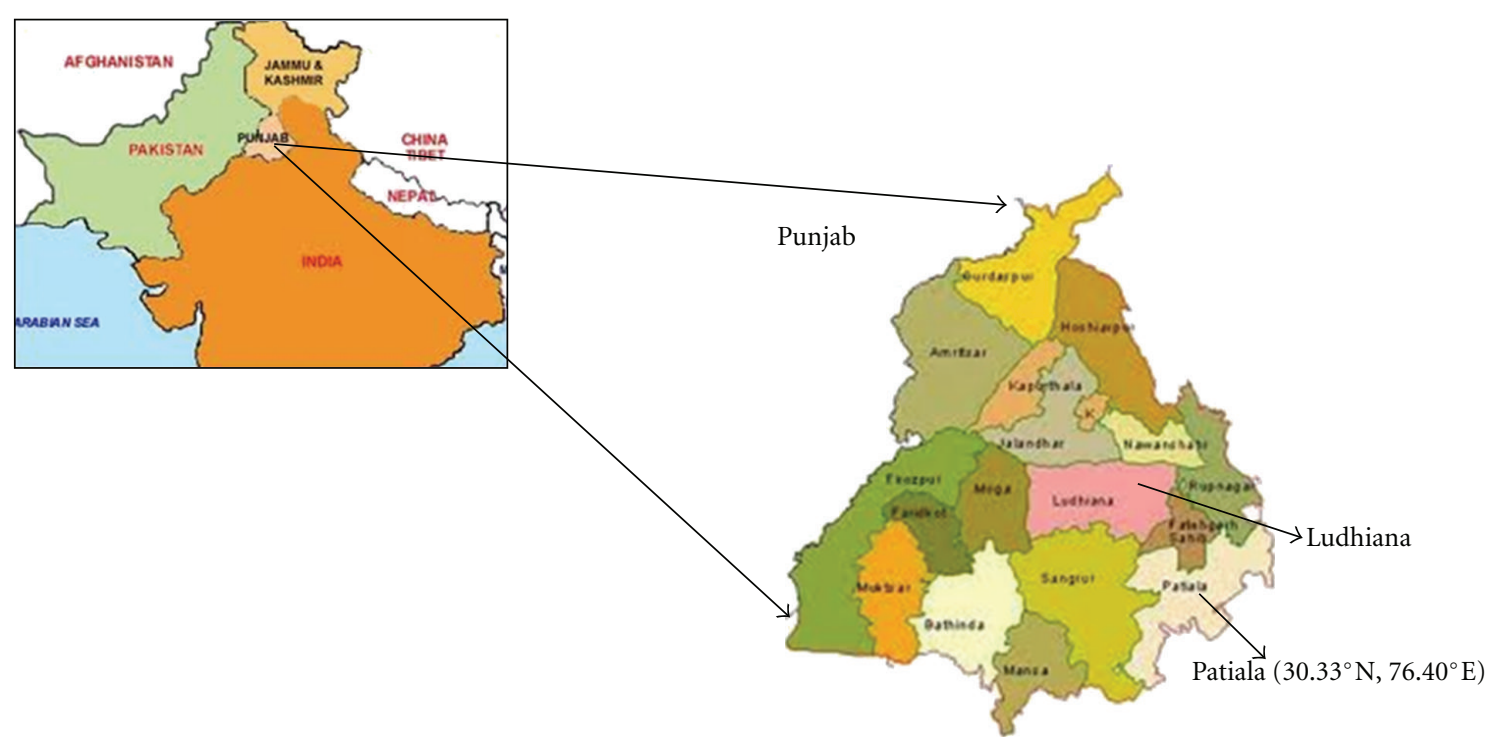

FIgURE 1: Site map for Patiala city $\left(30.33^{\circ} \mathrm{N}, 76.4^{\circ} \mathrm{E}, 249 \mathrm{~m}\right.$ a.s.l $)$ in northwestern India.

local anthropogenic pollution [24-27]. Moreover, measurements of particulate matter with diameter $<10 \mu \mathrm{m}$ (PM10) over IGP have shown high concentrations $\left(>150 \mu \mathrm{g} \mathrm{m}^{-3}\right)$ in many cities like Kanpur, Delhi, and Patiala, especially on dusty days $[28,29]$. These high PM10 concentrations are considered favorable for $\mathrm{SO}_{4}$ formation on the particulate surface leading to high concentration of sulfate aerosols in the atmosphere [30]. Thus, it will be interesting to examine how the naturally produced dust aerosols, mostly nonspherical in nature, modify the aerosol optical characteristics, and radiative forcing over northwestern India when they got mixed with locally generated anthropogenic pollution. Although, aerosol radiative forcing (ARF) is well examined over northwestern India [9, 31-34] and many references therein, studies focusing on ARF during major dust storms are rather few [35-38] and almost nonexistent over Punjab state.

In the present study, we analyze for the first time the optical properties of aerosols during dust events (DEs) over Patiala, Punjab state, India, inferred from ground-based measurements by Microtops-II (MT) sun photometer complimented with Aqua-MODIS and Aura-OMI satellite observations during April-June 2010. Moreover, back-trajectory analysis using HYSPLIT was used to study the pathways and possible source regions for the dust events. Apart from aerosol characteristics, calculations of ARF at surface (SRF), top of atmosphere (TOA), and within the atmosphere (ATM) are performed during the dusty days by means of OPAC and SBDART models.

\section{Site Description and Prevailing Synoptic Conditions}

The observational site is at rooftop of Physics Department in the Campus of Punjabi University, Patiala $\left(30.33^{\circ} \mathrm{N}\right.$, $76.40^{\circ} \mathrm{E}, 249 \mathrm{~m}$ a.s.l), located in the northwestern India
(Figure 1). The site is a semiurban area free from major industries and is surrounded by agro-based activities. However, industrial city Ludhiana is at about hundred kilometers away in the upwind northwest direction of the site, thus affecting the aerosol characteristics over the region. In the southwest of the observational site, the northeastern edge of the Thar Desert lies at a distance of few hundred kilometers, while Shivalik foothills lie at less than a hundred kilometers away in the northeast direction.

The climate of the region is semiarid with total rainfall of $\sim 750 \mathrm{~mm}$ occurring mostly in the monsoon season (July to September). The climatology of the area experiences four seasons, winter (December-March), premonsoon (PrM) (April-June), monsoon (July-September), and postmonsoon (October-November), with varying temperature, wind direction, humidity levels, rainfall amount, and aerosol types. Frequent hazy, fog, and pollution-smog conditions occur during winter December-January months decreasing the visibility, while the aerosols are mainly of anthropogenic origin over whole IGP [24]. The atmosphere over the region is engulfed with smoke most of the time with dim sunshine as paddy stubble is burnt by the farmers in the fields from second week of October up to mid-November $[39,40]$. The premonsoon season, in which the present study refers to, is characterized by frequent dust storms and dry spells of weather with scanty rain leading to high temperature. Prevailing southwesterly winds transport dust aerosols from Thar Desert and occurrence of occasional dust storms contributes to high loading of coarse-mode particles over the region [21].

The variation of various meteorological parameters, such as daytime air temperature, relative humidity $(\mathrm{RH})$, and wind speed (WS) as measured from the automatic weather station of the Indian Meteorological Department (IMD) observatory situated in the university campus is shown in Figure 2 during the study period. The daytime averaged temperature is high ranging from 35 to $42.8^{\circ} \mathrm{C}$ whereas the $\mathrm{RH}$ is low ranging from $20 \%$ to $50 \%$ for most of the days 

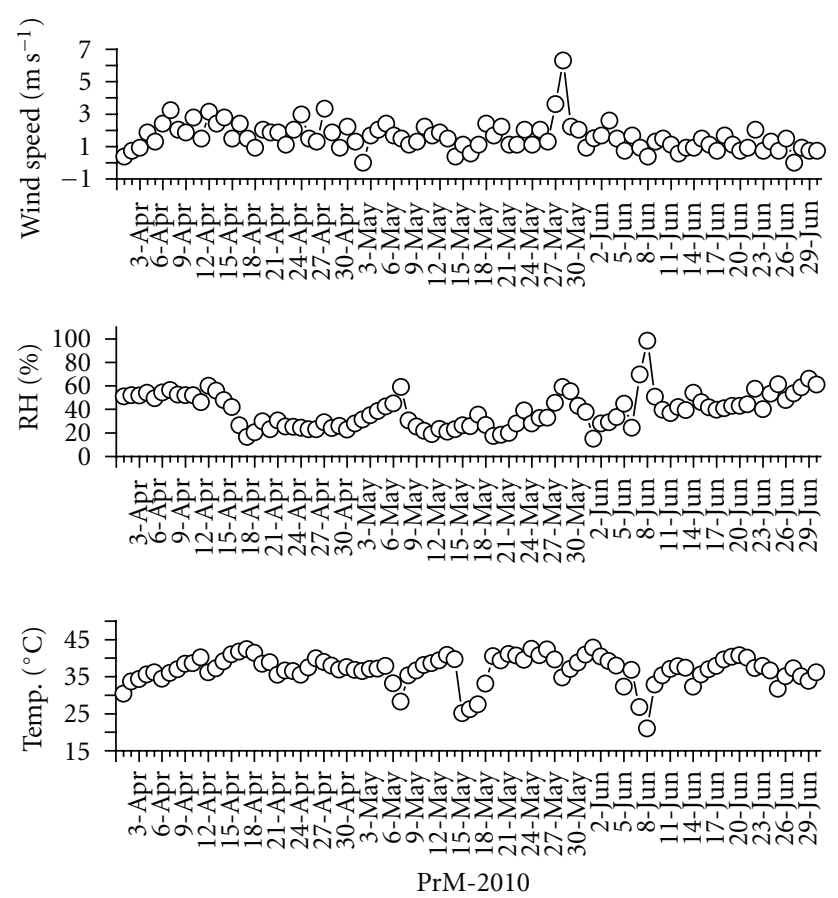

Figure 2: Day-to-day variation of the meteorological parameters (maximum temperature, relative humidity, wind speed) over Patiala during pre-monsoon season (April-June) of 2010.

except on cloudy or rainy days. Wind direction is mainly westerly/southwesterly with average WS ranging between 0.5 to $3.0 \mathrm{~ms}^{-1}$. The weather was mainly dry during the study period as sky was clear on 46 days; cloudy/partial cloudy conditions were observed on 35 days, whereas sporadic rainfall occurred on 10 days, mostly confined to the month of June.

\section{Datasets and Instrumentation}

3.1. Sun Photometer Measurements. A Solar Light portable microprocessor-controlled sun photometer and ozonometer Microtops-II (MT) was used to measure the spectral AOD at five wavelengths, namely, 380, 440,500, 675, and $870 \mathrm{~nm}$. The Full Width at Half Maximum (FWHM) bandwidth for $380 \mathrm{~nm}$ channel is $2.4 \pm 0.4 \mathrm{~nm}$ and $10 \pm 1.5$ for the other channels [41]. The MT has built-in pressure and temperature sensors with GPS connectivity to obtain the position and time coordinates. The measurement protocol is based upon the principal of measuring the intensity of incoming solar radiation at the particular wavelengths and, then, converts it into optical depth using its internal calibration and Langley method. The irradiance signal (in $\mathrm{mV}$ ) at different wavelengths is multiplied with the calibration factor (in $\mathrm{W} \mathrm{m} \mathrm{m}^{-2} \mathrm{mV}^{-1}$ ) and the absolute irradiance is obtained in $\mathrm{W} \mathrm{m}{ }^{-2}$. The combined effects of uncertainty in calibration, atmospheric pressure, total ozone amount, and so forth, result in total uncertainty in the computed spectral AODs of $\sim 0.01-0.025$, which is spectrally dependent with higher errors in the UV [42]. More details about the design, calibration, performance, and errors of MT are described elsewhere [19, 41, 42]. The sun photometric observations were systematically performed at Patiala under cloudless conditions from local sunrise to sunset.

The spectral dependence of AOD can be expressed by Ångström's empirical formula:

$$
\tau_{\lambda}=\beta \cdot \lambda^{-\alpha},
$$

where $\tau_{\lambda}$ is the AOD at a given wavelength $\lambda, \beta$ is Ångström's turbidity coefficient indicating the aerosol loading and is equal to AOD at $\lambda=1 \mu \mathrm{m}$ [43]. Taking the logarithm of both sides of (1) one obtains:

$$
\ln \tau_{\lambda}=-\alpha \ln \lambda+\ln \beta .
$$

Using (2) the Ångström exponent values were computed from spectral values of AOD at wavelengths $380 \mathrm{~nm}$ and $870 \mathrm{~nm}$ as

$$
\alpha=-\frac{d \ln \tau_{\lambda}}{d \ln \lambda}=-\frac{\ln \left(\tau_{\lambda 2} / \tau_{\lambda 1}\right)}{\ln \left(\lambda_{2} / \lambda_{1}\right)} .
$$

However, (2) usually departs from linearity due to incapability of (1) to simulate accurately the spectral AOD. This departure introduces a curvature into the $\ln \tau_{\lambda}$ versus $\ln \lambda$ relationship often occurs in sun photometry; thus, a second-order polynomial fit to $\ln \tau_{\lambda}$ versus $\ln \lambda$ (4) better simulates the spectral AOD variation $[44,45]$ :

$$
\ln \tau_{\lambda}=a_{2} \ln \lambda^{2}+a_{1} \ln \lambda+a_{0},
$$

where the coefficient $a_{2}$ accounts for the curvature with negative values corresponding to aerosol-size distribution dominated by fine-mode aerosols and vice versa $[44,45]$. The second order polynomial fit (4) was applied to spectral AOD values at six wavelengths $(380,440,500,675,800,870 \mathrm{~nm})$. Though the polynomial fit to (4) is more precise than the linear fit to (2), it is prone to errors especially under low turbidity conditions [43]. In the present work, only those cases of second-order polynomial fit having $R^{2}>0.99$ were considered for the analysis.

3.2. MODIS AOD Retrievals. Moderate Resolution Imaging Spectroradiometer (MODIS) onboard polar orbiting NASA's Earth Observing System (EOS) Terra and Aqua spacecrafts provides daily global data of aerosol characteristics using 36 spectral bands ranging from visible to thermal infrared $(0.41-14.38 \mu \mathrm{m})$, with spatial resolutions of $1000 \mathrm{~m}, 500 \mathrm{~m}$, and $250 \mathrm{~m}$ (pixel size at nadir) [46]. Some of these bands are used for aerosol retrievals over both land and ocean surfaces with the use of separate algorithms with retrieval uncertainty of $\pm 0.03 \pm 5 \%$ [47] over ocean and $\pm 0.05 \pm 15 \%$ over land [48]. In the present study, collection 5 (C005) Level 3 AquaMODIS AODs at $550 \mathrm{~nm}$ were obtained for pixel centered over Patiala on the dusty days as well as pre- and postdusty days from Giovanni website (http://giovanni.gsfc.nasa.gov/). The level $3 \mathrm{AOD}$ retrievals (spatial resolution of $1^{\circ} \times 1^{\circ}$ ) were computed from level $2(10 \mathrm{~km} \times 10 \mathrm{~km})$ by applying specific logic in screening clouds as described elsewhere [49]. After modifying the irregularities in level 2 data over space and time, the resulting level 3 MODIS products are available on daily and monthly basis, globally, and on a grid. 
TAble 1: Values of Aqua-MODIS AOD 550 , MICROTOPS-II AOD A00 , Aura-OMI AI, and Ångström parameters for six days with DE over Patiala, northwestern India during premonsoon season of 2010.

\begin{tabular}{lccccccc}
\hline Start Date & $\begin{array}{c}\text { Intense } \\
\text { Period }\end{array}$ & End Date & AOD $_{550}$ (MODIS-Aqua) & AOD $_{500}(\mathrm{MT})$ & $\begin{array}{c}\text { AI } \\
\text { (OMI-Aura) }\end{array}$ & $\alpha_{380-870}$ & Beta \\
\hline April 15 & April 21 & April 24 & 1.34 & 1.13 & 6.30 & 0.31 \\
May 12 & May 14 & May 16 & 0.59 & 0.53 & 2.93 & 0.59 \\
May 21 & May 23 & May 25 & 0.84 & 0.84 & 2.82 & 0.60 \\
May 26 & May 28 & May 31 & 1.87 & 1.52 & 6.74 & 0.14 \\
May 31 & Jun 01 & Jun 03 & 0.59 & 0.50 & 2.65 & 0.57 \\
Jun 05 & Jun 06 & Jun 08 & 0.77 & 0.53 & 2.01 & 0.45 \\
\hline
\end{tabular}

3.3. OMI Aerosol Index (AI) Retrievals. The Aerosol Index (AI) is an important parameter that is highly useful for the detection of absorbing aerosols, like desert dust and/or Black Carbon (BC), in the atmosphere [50]. Positive values of AI indicate the presence of UV-absorbing aerosols whereas the negative values correspond to nonabsorbing particles, for example, sulphate [51]. Ozone Monitoring Instrument (OMI) is the Dutch-Finnish contribution to NASA EOSAura platform launched in July 2004 and is able for AI retrievals over the globe among many other aerosol and ozone properties via the OMI multiwavelength algorithm $[52,53]$. Contrary to MODIS, OMI-AI is also sensitive to aerosol absorption when aerosols are above clouds and, hence, AI is successfully derived for both cloudless and cloudy conditions [54]. However, a disadvantage of AI for considering it as a measure of the aerosol loading in the atmosphere is its strong dependence on aerosol altitude, while any aerosol layer below $\sim 1000 \mathrm{~m}$ is difficult to be detected [54]. In the present study, AI has been derived from Aura-OMI Level 2G daily gridded data products generated by NASA OMI science team by binning the original pixels from the level $2(13 \mathrm{~km} \times 24 \mathrm{~km}$ spatial resolution at nadir $)$ into $0.25^{\circ} \times 0.25^{\circ}$ global grids available on Giovanni website (http://giovanni.gsfc.nasa.gov/).

3.4. Back Trajectories. The Hybrid Single-Particle Langrangian Integrated Trajectory (HYSPLIT) model [55] has been used to compute air-mass back trajectories over Patiala for the six DE during April-June 2010. The back trajectories were computed for the past 120 hours ( 5 days) at three altitudes, such as $500 \mathrm{~m}, 1500 \mathrm{~m}$, and $4000 \mathrm{~m}$, in order to identify the pathways of local and long-range transported dust. Back trajectory analysis is widely used in conjunction with optical properties of aerosols in order to identify different types of aerosols and source regions [56].

\section{Results and Discussion}

4.1. Identification of Dust Events (DEs). During the premonsoon period, frequent dust storms occur over the study region increasing the aerosol loading, reducing the visibility and, hence, affecting the physical and optical properties of aerosols. Middleton [57] found higher frequency for DE occurrence in the western part as compared to the eastern part of the IGP with maximum frequency in the months of

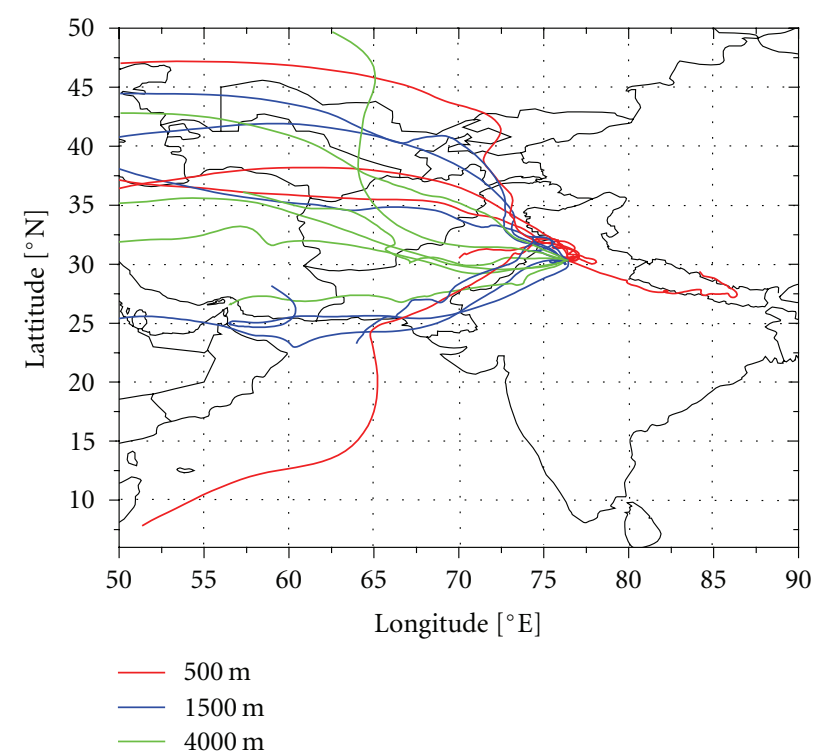

FIGURE 3: Five-days air mass back-trajectories ending at Patiala (HYSPLIT model) at three different altitudes, $500 \mathrm{~m}, 1500 \mathrm{~m}$, and $4000 \mathrm{~m}$, on the six dusty days (see Table 1).

May and June. Average $\mathrm{AOD}_{500}$ over various locations in IGP during premonsoon period remain high $(>0.5)$ associated with low $\alpha<1$ [58]. In the present study, values of MT$\mathrm{AOD}_{500}>0.5$ associated with OMI-AI $>2.0$ and values of $\alpha<0.7$ are associated to DE over Patiala; six DE were identified during the study period (April-June 2010) with aerosol characteristics as summarized in Table 1. Out of these six DE, those occurred on April 21, 2010, and May 28, 2010, are identified as the most intense and permanent DE.

Chemical analysis and air-mass back trajectories over IGP have shown that the dust originates from three major sources, namely, Oman, southwest Asia (Iran, Pakistan), and Thar Desert in Rajasthan [59-61]. In the present study, the air-mass back trajectories at the three altitudes $(500 \mathrm{~m}$, $1500 \mathrm{~m}$ and $4000 \mathrm{~m}$ ) show that the air masses during the DE are passing over the Thar Desert before reaching the observational site (Figure 3). On the other hand, long-range dust transport from Arabian Peninsula and Middle East, mainly at higher altitudes, also contributes to the high AODs during the dusty days. 


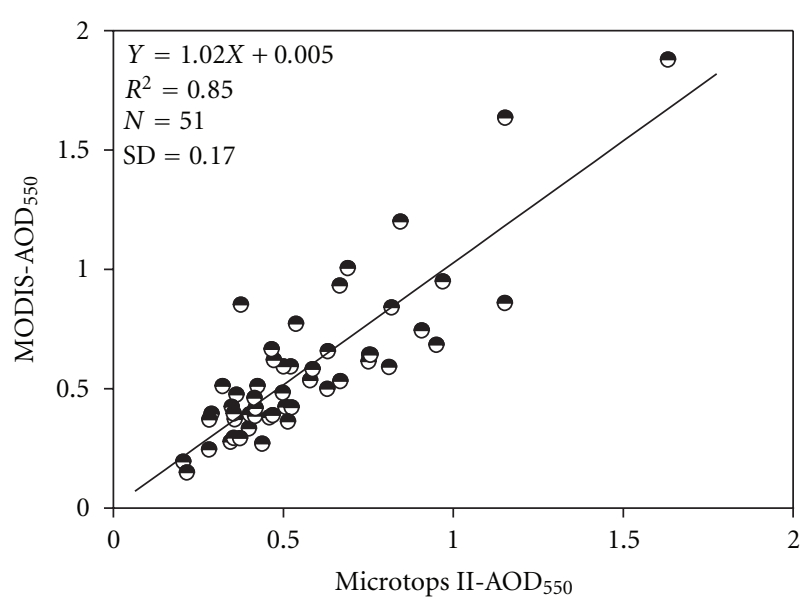

Figure 4: Correlation of Aqua-MODIS AOD ${ }_{550}$ versus Microtops-II $\mathrm{AOD}_{550}$ at the same hour of the Aqua overpass over Patiala during pre-monsoon season (April-June) of 2010.

4.2. Aerosol Optical Properties. The dust storm events during the premonsoon season of 2010 over Patiala have been studied from the synergy of ground-based and satellite observations. A satisfactory agreement $\left(R^{2}=0.85\right)$ between Aqua-MODIS $\mathrm{AOD}_{550}$ with MT-AOD ${ }_{550}$ during the whole premonsoon season (April-June) was found (Figure 4) suggesting that monitoring of aerosol properties over the region using satellite-based techniques has reasonable accuracy. The MT-AOD ${ }_{550}$ values were calculated from $\mathrm{AOD}_{500}$ using the $\alpha$ value for that time interval, while the MT AODs correspond to $\pm 30 \mathrm{~min}$ from the Aqua overpass ( $\sim 13: 30$ LST). Table 1 shows the day-to-day variation of aerosol characteristics during the six DE as observed from MT, Aqua-MODIS, and OMI. The average value of $\mathrm{AOD}_{550}$ based on AquaMODIS data is $1.00 \pm 0.51$ with peak value of 1.87 that are comparable to $\mathrm{MT}$ mean and maximum $\mathrm{AOD}_{500}$ values of $0.84 \pm 0.41$ and 1.52 , respectively. On the other hand, the OMI-AI reaches to a maximum value of 6.74 on 28 May 2010, when the most intense DE takes place. The average values of Ångström exponent $(\alpha)$ and turbidity parameter $(\beta)$ are $0.39 \pm 0.19$ and $0.69 \pm 0.41$, respectively.

Figure 5 shows the spectral variation of MT AODs during the six DE. The wavelength dependence of AOD seems to be rather low, especially during the intense DE on 21 April and 28 May. However, the wavelength dependence of the AOD differs significantly for the various DE and is highly dependent on intensity of dust storms, the coarse-to-fine ratio, the particle size, the columnar size distribution, and the mixing processes with anthropogenic aerosols in the atmosphere $[25,26]$. Figures $6(a)-6(d)$ show the spatial distribution of Aura-OMI AI and Aqua-MODIS AOD 550 over the Indian subcontinent during the most intense DE, that is, April 21 and May 28, 2010. The AI values are very high $(>4.5)$ and cover a large area over northern India and IGP suggesting abundance of UV-absorbing aerosols at higher altitudes. Similarly, during the intense DE, values of $\mathrm{AOD}_{550}>0.9$ occur over northwestern and central IGP, indicating enhanced presence of dust aerosols; this is

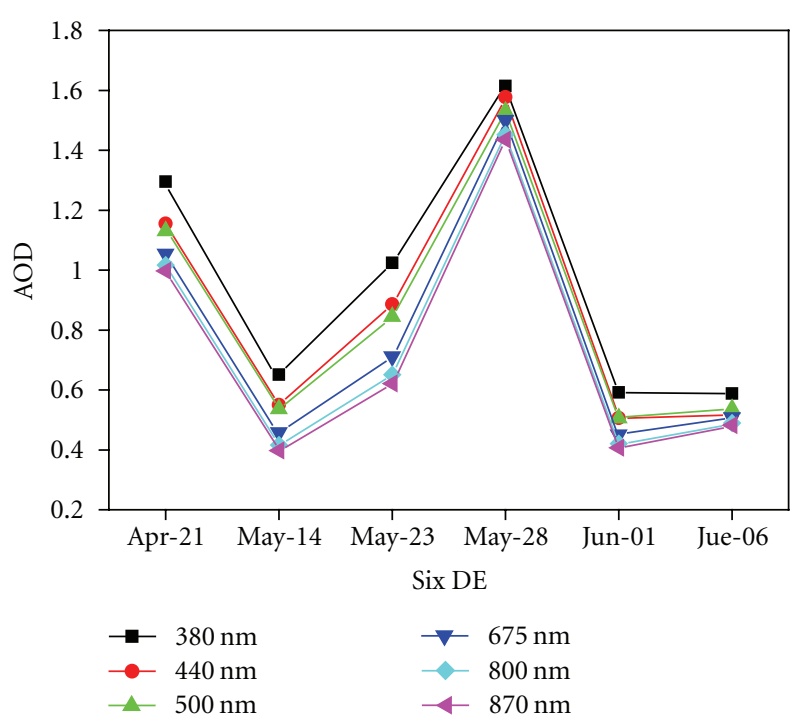

FIgURE 5: Spectral variation of Microtops-II AOD during the six DE.

suggested in combination with the extremely high AI and the air-mass trajectories revealing originality from the desert and arid regions of southwest Asia (Figure 3).

Dey et al. [25] have studied the aerosol characteristics during major dust storms over Kanpur, located in central part of IGP, in the month of May during the years 2001 and 2002. They reported more than 50\% increase in AOD for each DE with maximum values approaching to 1.281.70 comparable to the present ones (Table 2). Moorthy et al. [60] performed a study over Thar Desert finding that the aerosols are more absorbing in nature compared to African dust, also reporting higher $\mathrm{AOD}_{1025}$ than $\mathrm{AOD}_{500}$ in several cases suggesting dominance of coarse-mode particles. Hedge et al. [35] emphasized on an intense DE (12 June, 2006) over a hill station (Nainital) in northwestern India founding that the aerosol number concentrations in the coarse and giant modes increased by a factor of five and ten, respectively, as compared to their respective monthly mean values. The effect of $\mathrm{DE}$ is more pronounced at longer wavelengths in comparison to shorter ones indicating a shift in aerosol distribution towards larger size during a dust storm $[4,26,61]$. Similarly, in the present study, there is a significant decrease in the magnitude of $\alpha$ and correspondingly increase in values of $\beta$ during the most intense DE on 28 May (Table 1).

\subsection{Aerosol Optical Properties and Solar Flux during \\ Intense DE}

4.3.1. Dust Event of April 16-24, 2010. During April 2010, an intense dust storm hit the study area on April 16 resulting to significant increase of $\mathrm{AOD}_{500}$ from 0.37 on 15 April to 0.76 on the next day (Table 2). Accordingly, Ångström exponent $\alpha$ decreases from 0.50 to 0.27 and turbidity parameter $\beta$ increases from 0.26 to 0.63 indicating significant increase in aerosol loading especially in the coarse mode. As a result, day averaged diffuse solar flux increases from $172.4 \mathrm{Wm}^{-2}$ 


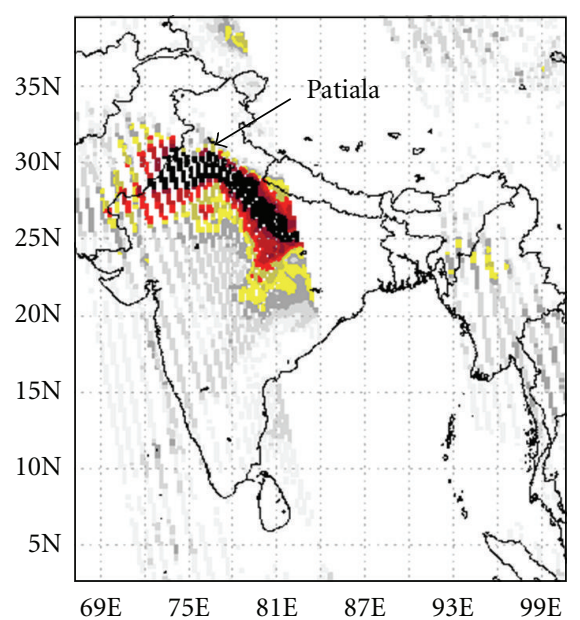

(a)

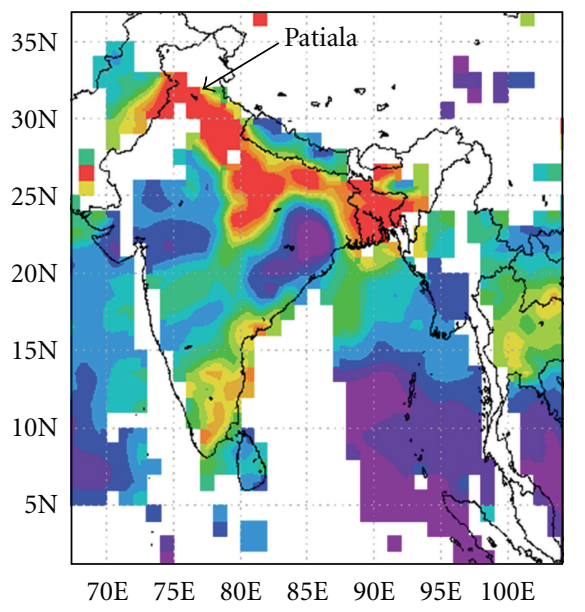

(c)
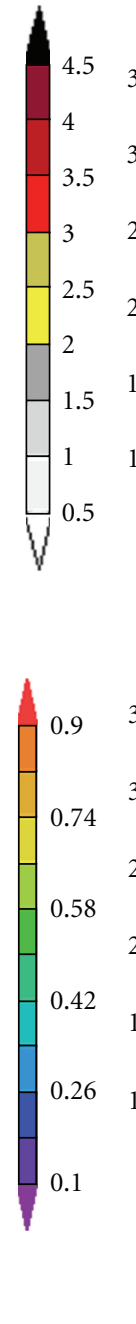

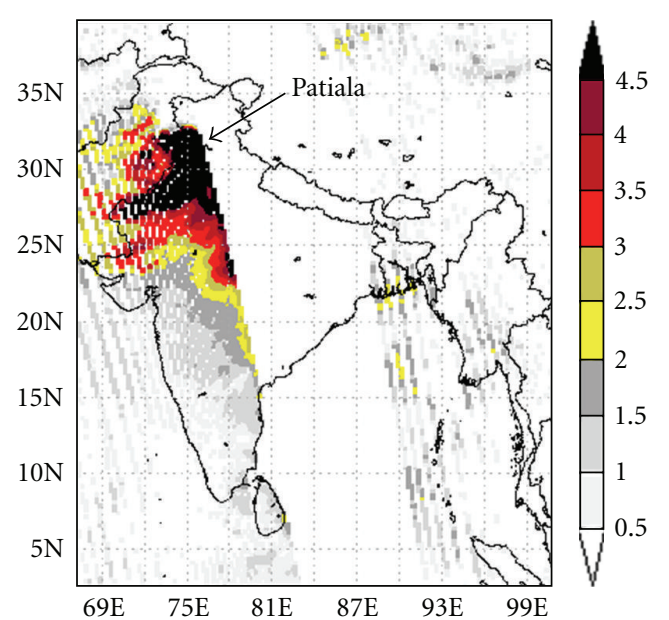

(b)

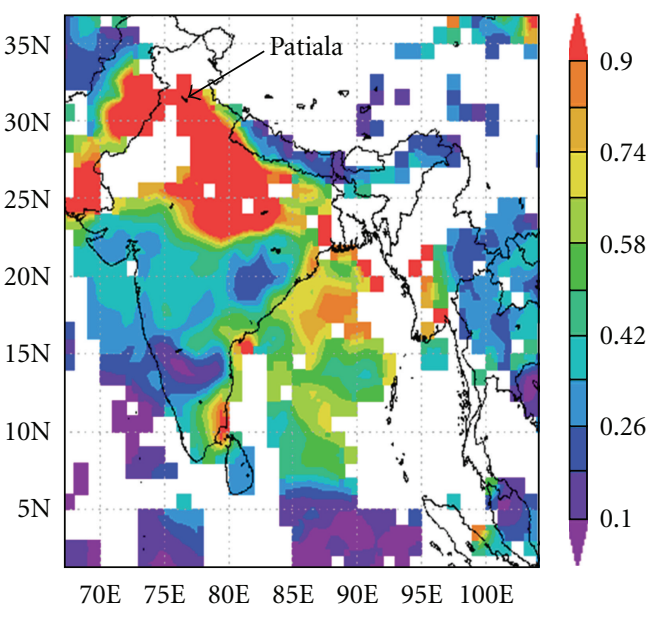

(d)

Figure 6: Spatial distribution of OMI-AI (a, b) and Aqua-MODIS AOD 550 (c, d) over India during the two intense DE, 21 April 2010 (a, c) and 28 May 2010 (b, d).

to $252.9 \mathrm{Wm}^{-2}$ due to increased scattering and reduction in direct-beam solar flux from $384.4 \mathrm{Wm}^{-2}$ to $250.0 \mathrm{Wm}^{-2}$. Though $\mathrm{AOD}_{500}$ remains almost at the same level till April 18, it attains the highest value of 1.01 from April 19 to April 21, during the intensity of the dust storm, and weakens thereafter to a minimum value of 0.36 on April 24 indicating the end of dust storm and the dilution of dust aerosols. During the intense period of the dust storm, AI attains peak value of $6.3, \alpha$ exhibits its lowest values ranging between 0.27 and 0.31 , while $\beta$ increases to values of $0.80-0.95$. The averaged direct-beam solar flux reduces to a minimum value of $44.87 \mathrm{Wm}^{-2}$ while the diffuse component increases to its maximum value of $316.66 \mathrm{Wm}^{-2}$ on 21 April 2010.

4.3.2. Dust Event of May 26-31, 2010. The second dust storm started building up on 26 May 2010 when $\mathrm{AOD}_{500}$ increases to 0.5 and $\alpha$ decreases to 0.54 and, thereafter, it intensifies on 27 May when $\mathrm{AOD}_{500}$ approaches to 0.76 and $\alpha$ further reduces to 0.31 (Table 2). The dust storm reaches to its maximum intensity on 28 May when Aqua-MODIS AOD 550 becomes 1.87, MT $\mathrm{AOD}_{500} 1.52$, and $\mathrm{AI}$ approaches to a maximum value of 6.74; the Ångström exponent $\alpha$ comes down to its lowest value of 0.14 , the turbidity parameter $\beta$ increases to its highest value of 1.4 suggesting highly turbid atmospheric conditions. The highly turbid atmosphere results in significant increase in the diffuse component to $287.5 \mathrm{Wm}^{-2}$, while the direct-beam component reduces to $126.9 \mathrm{Wm}^{-2}$, corresponding to a mean reduction of $66 \%$ from the predust storm conditions. Moreover, using the Volz method [62], the $\alpha$ values were calculated in two narrow spectral intervals $(380-440 \mathrm{~nm}$ and $675-870 \mathrm{~nm})$ using MT AODs via (3). Errors and uncertainties in such calculations have been discussed elsewhere [63]. The positive or negative values of the difference $\alpha_{380-440}-\alpha_{675-870}$ correspond, in general, to positive or negative values of the curvature of the $\ln$ AOD versus $\ln \lambda$ (coefficient $a_{2}$ ) [64], with the positive values to suggest dominance of coarse-mode particles. In the present study (Figures $7(\mathrm{a}), 7(\mathrm{~b})$ ), the differences are found to be positive in all cases, exhibiting a decreasing trend, that is, approaching to zero as AOD increases (Figure $7(a)$ ). This suggests negligible wavelength dependence of $\alpha$, with the second-order polynomial fit (4) to approach linearity (2). 
TAble 2: Daily mean values of MT and MODIS AOD, OMI-AI, $\alpha_{380-870}, \beta$, direct solar flux, and diffuse solar flux at Patiala during dusty, predusty and postdusty days in the premonsoon season of 2010.

\begin{tabular}{|c|c|c|c|c|c|c|c|}
\hline Date & $\mathrm{AOD}_{500}$ & $\begin{array}{c}\mathrm{AOD}_{550} \\
\text { (Aqua-MODIS) }\end{array}$ & $\begin{array}{c}\text { UV-AI } \\
\text { (OMI-Aura) }\end{array}$ & $\alpha_{380-870}$ & $\operatorname{Beta}(\beta)$ & $\begin{array}{c}\text { Direct } \\
\text { Solar Flux } \\
\left(\mathrm{W} \mathrm{m}^{-2}\right)\end{array}$ & $\begin{array}{c}\text { Diffuse } \\
\text { Solar Flux } \\
\left(\mathrm{W} \mathrm{m}^{-2}\right)\end{array}$ \\
\hline 15-April-10 & 0.37 & 0.29 & - & 0.50 & 0.26 & 384.40 & 172.43 \\
\hline 16-April-10 & 0.76 & 0.64 & 2.66 & 0.27 & 0.63 & 250.00 & 252.99 \\
\hline 17-April-10 & - & 0.602 & - & - & - & 264.74 & 239.10 \\
\hline 18-April-10 & - & - & - & - & - & 120.08 & 288.67 \\
\hline 19-April-10 & 1.01 & - & 1.55 & - & - & 114.10 & 300.21 \\
\hline 20-April-10 & 0.96 & 0.683 & - & 0.27 & 0.80 & 220.70 & 256.41 \\
\hline 21-April-10 & 1.13 & 1.34 & 6.30 & 0.31 & 0.95 & 44.87 & 316.66 \\
\hline 22-April-10 & - & 0.85 & - & - & - & 166.23 & 294.65 \\
\hline 23-April-10 & 0.51 & 0.42 & - & 0.25 & 0.43 & 359.40 & 185.04 \\
\hline 24-April-10 & 0.36 & 0.47 & - & 0.61 & 0.25 & 302.77 & 203.63 \\
\hline 12-May-10 & 0.303 & 0.39 & 2.27 & 0.78 & 0.18 & 367.65 & 224.00 \\
\hline 13-May-10 & 0.40 & 0.48 & 2.75 & 0.69 & 0.27 & 268.65 & 223.80 \\
\hline 14-Мау-10 & 0.53 & 0.59 & 2.93 & 0.59 & 0.36 & 340.27 & 214.68 \\
\hline 15-May-10 & 0.50 & 0.42 & - & 0.6 & 0.39 & 373.21 & 194.44 \\
\hline 16-Мay-10 & - & 0.51 & 2.61 & - & - & 312.89 & 178.17 \\
\hline 21-May-10 & 0.29 & 0.37 & 1.72 & 0.87 & 0.16 & 468.25 & 128.96 \\
\hline 22-Мay-10 & 0.54 & 0.36 & - & 0.86 & 0.37 & 363.09 & 173.80 \\
\hline 23-May-10 & 0.84 & 0.84 & 2.83 & 0.60 & 0.57 & 286.90 & 233.13 \\
\hline 24-May-10 & 0.64 & 0.49 & - & 0.50 & 0.46 & 329.96 & 213.49 \\
\hline 25-Мау-10 & 0.43 & 0.41 & - & 0.48 & 0.31 & 400.19 & 174.40 \\
\hline 26-May-10 & 0.47 & 0.38 & - & 0.54 & 0.33 & 371.82 & 165.27 \\
\hline 27-May-10 & 0.76 & 0.64 & - & 0.31 & 0.62 & 283.13 & 231.74 \\
\hline 28-May-10 & 1.52 & 1.87 & 6.74 & 0.14 & 1.40 & 126.98 & 287.5 \\
\hline 29-May-10 & 0.90 & 0.74 & 3.86 & 0.12 & 0.84 & 268.45 & 270.83 \\
\hline 30-May-10 & - & 0.54 & 2.12 & - & - & 372.22 & 200.29 \\
\hline 31-May-10 & 0.37 & 0.29 & - & 0.49 & 0.27 & 444.64 & 152.97 \\
\hline 01-Jun-10 & 0.50 & 0.59 & 2.65 & 0.45 & 0.38 & 362.50 & 202.97 \\
\hline 02-Jun-10 & - & 1.16 & - & - & - & - & - \\
\hline 03-Jun-10 & 0.48 & 0.89 & 0.97 & 0.83 & 0.26 & 197.61 & 286.50 \\
\hline 05-Jun-10 & - & - & 1.68 & - & - & - & - \\
\hline 06-Jun-10 & 0.53 & 0.77 & 1.98 & 0.23 & 0.46 & 188.29 & 324.00 \\
\hline 07-Jun-10 & 0.38 & - & - & 0.35 & 0.58 & - & - \\
\hline 08-Jun-10 & - & 0.52 & - & - & - & - & - \\
\hline
\end{tabular}

These results are in agreement with earlier observations by Eck et al. [44] and Kaskaoutis et al. [64], who found negligible spectral variations of $\alpha$ during high turbid conditions over arid environments. The Figure 7(b) shows the daily variation of the differences in $\alpha$ during the study period.

4.4. OPAC Retrievals. As aerosols are mainly a mixture of both scattering and absorbing types in the atmosphere, their effects in terms of cooling or warming of the planetary system depends on several parameters, on which single scattering albedo (SSA) plays a major role $[65,66]$. Except of SSA, the radiative forcing of aerosols depends mainly on spectral $\mathrm{AOD}$, water vapor content in the atmosphere, ozone amount, asymmetry parameter, surface albedo, vertical distribution of aerosols, as well as the relative height between aerosols and clouds $[9,23,31]$.
For the calculation of ARF the above parameters are used as inputs in radiative transfer codes. Since there are no observations of SSA and asymmetry parameter, the Optical Properties of Aerosols and Clouds (OPAC) software package by Hess et al. [67] has been used to estimate the optical properties of composite aerosols (SSA and asymmetry parameter). This model has been widely adopted as it describes a wide range of possible aerosol composition from which a mixture of aerosol can be obtained [68-70]. According to the prevailing atmospheric conditions over the study area, the mixture of aerosols, which was used for the present study is composed of water-soluble, insoluble, BC (soot), minerals (accumulation mode), and minerals transported aerosols. BC mass concentration in Patiala was measured via Aethalometer based on the optical attenuation technique with an uncertainty of $\sim 20 \%$ [60]. Moreover, a high-volume 


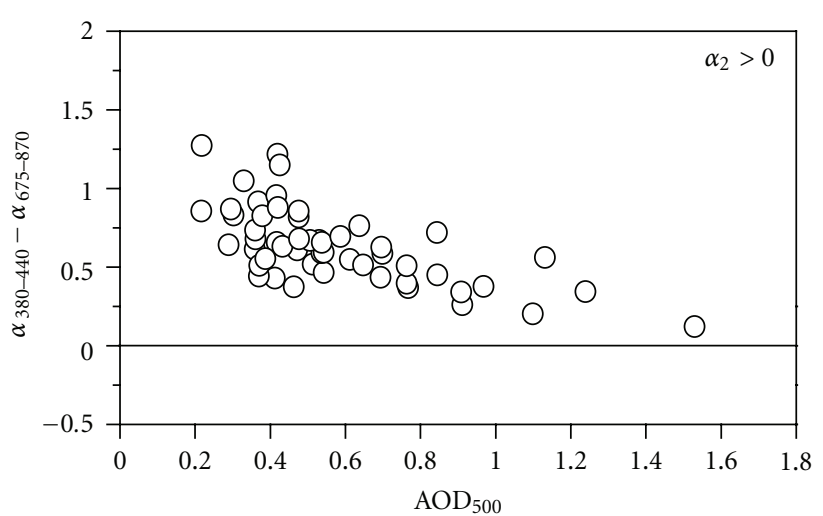

(a)

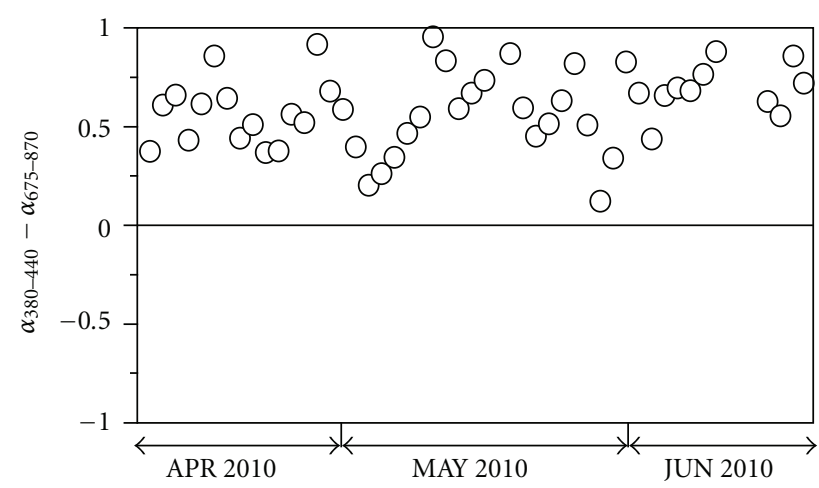

(b)

FIgURE 7: Scatter plot of $\alpha_{380-440}-\alpha_{675-870}$ versus $\mathrm{AOD}_{500}$ (a), and day-to-day variation of the difference $\alpha_{380-440}-\alpha_{675-870}$ during the premonsoon season of 2010 (b).

sampler was used for measurements of the mass concentration of composite aerosols with average uncertainty of $\sim 15 \%$. By means of these two instruments, the BC mass mixing ratio (ratio of the mass concentration of $\mathrm{BC}$ to the total mass of the composite aerosols) was measured during the days of interest. By fixing the $\mathrm{BC}$ mass mixing ratio, the number of densities of the other aerosol components varied, and the number of iterations performed till estimated spectral AOD almost matches with the measured spectral MT AOD $[9,68]$. The OPAC-simulated aerosol optical properties are considered satisfactory when the spectral OPAC-AOD is within $5 \%$ uncertainty with the measured one via MT. The value of $\mathrm{RH}$ is crucial in the reconstruction of the spectral AOD and, thus, OPAC permits the use of eight values of RH $(0 \%, 50 \%, 70 \%, 80 \%, 90 \%, 95 \%, 98 \%$, and 99\%); the value closest to the mean $\mathrm{RH}$ prevailing on each day was selected in the present study. From the above procedure, the OPAC-simulated spectral aerosol properties were obtained for the dusty days as well as for days before and after the maximum intensity of dust. It should be noted that OPAC simulations were performed only for days with sun photometer observations over Patiala in order to estimate the ARF during dusty and nondusty days.

Figure 8 shows the spectral variations of SSA during, before and after the two intense dust storms over Patiala. It is observed that SSA is wavelength dependent and increases with wavelength on the dust storm days, but its magnitude decreases with wavelength during nondusty days (days of lowest $\mathrm{AOD}_{500}$ ). The increase of SSA with wavelength clearly suggests more scattering at higher wavelengths due to increased concentration of coarse-mode particles [25]. During the two intense DE, the SSA values lie in the range of 0.88 to 0.92 with the peak values of SSA at $675 \mathrm{~nm}$ to be 0.925 and 0.924 on 21 April, 2010, and 28 May, 2010, respectively. Such values of SSA suggest the dominance of scattering coarse-mode aerosols mixed also with local pollution that are comparable to those observed over northwestern India during premonsoon $[22,71]$.

4.5. Aerosol Radiative Forcing. Aerosol radiative forcing (ARF) at the top of the atmosphere (TOA) and at the surface

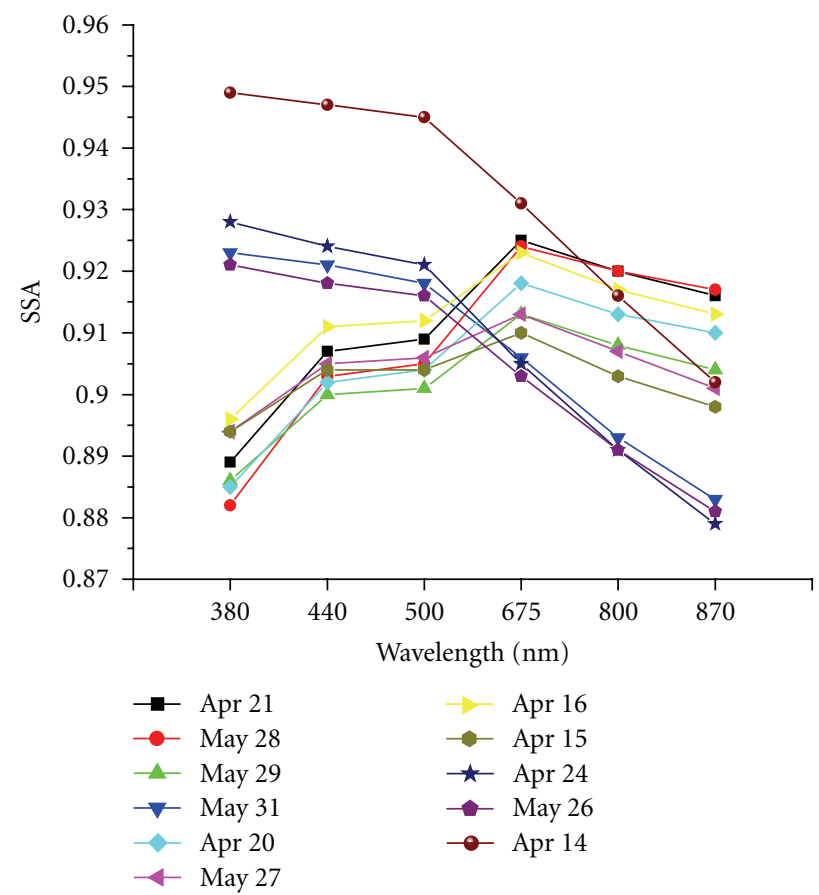

FIGURE 8: Spectral variation of OPAC-derived SSA values during dusty days over Patiala.

(SRF) is defined as the difference in the net shortwave solar radiation flux (down minus up) with and without aerosols at the TOA and at the surface, respectively,

$$
(\Delta F)_{S, \mathrm{TOA}}=\left(F_{\mathrm{NA}}\right)_{S, \mathrm{TOA}}-\left(F_{\mathrm{A}}\right)_{S, \mathrm{TOA}},
$$

where $\Delta F$ is the net change in radiation flux $F$, and $F_{\mathrm{NA}}$ and $F_{A}$ correspond to shortwave fluxes without and with aerosols, respectively, while the subscripts $S$ and TOA refer to Earth's surface and TOA, respectively [72]. The direct ARF involves scattering and absorption of solar radiation by atmospheric aerosols, which, depending upon the nature of aerosols, their distribution, and surface albedo, may produce negative or positive radiative forcing. The absorbing aerosols, like BC 


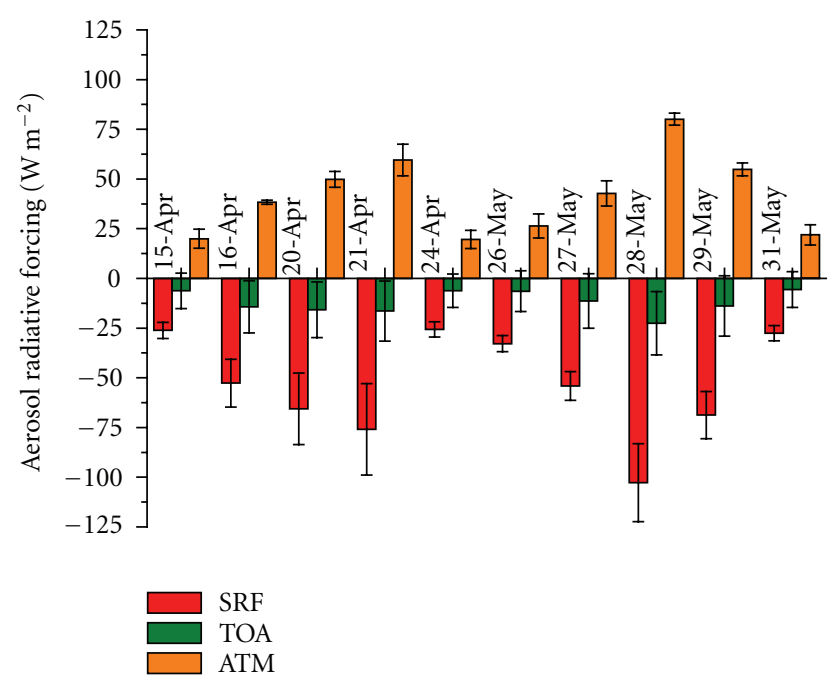

FIGURE 9: Variation of aerosol radiative forcing values at SRF, TOA and ATM during dusty days over Patiala during the pre-monsoon season of 2010 .

and some of the mineral dust aerosols, alter significantly the magnitude and sign of the ARF by altering the aerosol SSA [66]. A negative value of TOA forcing implies more radiation lost to space by enhanced backscattering due to aerosols leading to cooling of the Earth-atmosphere system, while the presence of absorbing aerosols results in positive radiative forcing implying warming of the atmosphere. ARF at surface is always negative because aerosols attenuate (scatter and absorb) the surface reaching solar radiation. The difference between the radiative forcing at the TOA and at the surface defines the atmospheric radiative forcing (ATM):

$$
(\Delta F)_{\mathrm{Atm}}=(\Delta F)_{\mathrm{TOA}}-(\Delta F)_{S} .
$$

In the present study, ARF calculations are computed in the shortwave spectrum $(0.25-4.0 \mu \mathrm{m})$ separately for SRF, ATM and TOA using the Santa Barbara Discrete-ordinate Atmospheric Radiative Transfer (SBDART) model developed at University of California, Santa Barbara [73]. SBDART computes plane-parallel radiative transfer calculations both in clear and cloudy sky conditions within the Earth's atmosphere and at the surface and has been extensively used for ARF calculations over India [9, 32-34, 74].

ARF is strongly dependent upon spectral AOD, SSA, scattering phase function as well as surface albedo and meteorological conditions. For the estimation of shortwave ARF, the measured spectral AOD was used as input in the model as well as the aerosol optical parameters simulated from OPAC, namely, spectral SSA and asymmetry parameter (g). The model was run at hourly intervals for 24-hour period and the daily averaged ARF was estimated on each day of interest (Figure 9). Other input parameters essential for SBDART estimates include the solar geometry, a model atmosphere, and the surface albedo. The surface albedo $(0.15 \pm 0.009)$ was obtained using MODIS albedo product (MODIS/Terra + Aqua albedo 16-day L3 global $1 \mathrm{~km} \mathrm{SIN}$ Grid V005), which provides both white-sky albedo (WSA) as

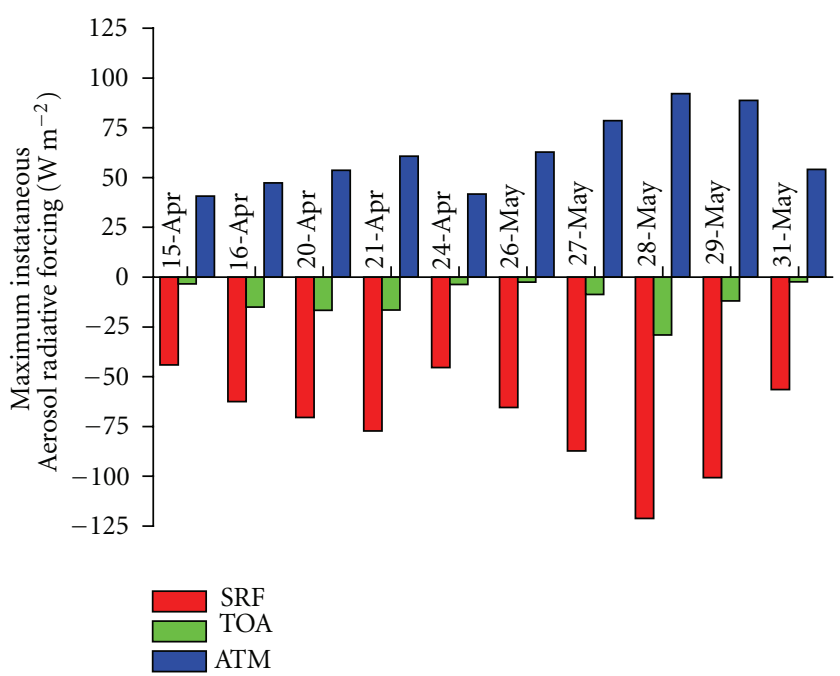

FIGURE 10: Same as in Figure 9, but for the maximum instantaneous ARF values.

well as black-sky albedo (BSA) for MODIS spectrum 0.645$2.13 \mu \mathrm{m}$ (http://reverb.echo.nasa.gov/reverb/). Based on the prevailing weather conditions over the study region, we have used the mid-latitude summer atmospheric profile in the model. The model was run with eight streams to obtain the TOA and surface ARF. The uncertainties in shortwave ARF calculations could arise from various assumptions, such as model atmosphere, OPAC simulations, as well as uncertainties in surface albedo, molecular scattering absorption, and errors in measured parameters, such as AOD, BC mass concentration. The overall uncertainty in ARF calculations does not exceed $20 \%[36,75]$.

The daily averaged as well as maximum instantaneous values of ARF at TOA, SRF, and ATM were estimated for the two dust-storm periods (16-24 April, 2010 and 26-31 May, 2010) and are shown in Figures 9 and 10, respectively. It should be noted that some days during the abovementioned periods are missing due to lack of MT AODs. The daily averaged SRF ARF values are low $\left(-26.1 \mathrm{Wm}^{-2}\right.$ and $-32.8 \mathrm{Wm}^{-2}$ ) at the beginning of each dust event. As the dust storms built up and AODs become high, the SRF attains its maximum ARF values of $-75.9 \mathrm{Wm}^{-2}$ and $-102.6 \mathrm{Wm}^{-2}$ on April 21 and May 28, respectively (Figure 9). Similar pattern is seen in the variations of maximum instantaneous SRF ARF that attains maximum values of $-77.3 \mathrm{Wm}^{-2}$ and $-121.9 \mathrm{Wm}^{-2}$ on April 21 and May 28, respectively (Figure 10). Similarly, daily averaged TOA forcing and instantaneous maximum TOA ARF values of $-16.4 \mathrm{Wm}^{-2}$, $-22.6 \mathrm{Wm}^{-2}$ and $-16.5 \mathrm{Wm}^{-2},-29.0 \mathrm{Wm}^{-2}$, respectively, for the same days indicate more scattering of solar radiation back to space than the normal days supporting our view that the dust particles transported over the region are of scattering nature. Accordingly, the ATM ARF is positive and its magnitude also increases with the intensity of the dust storm, reaching to its peak value of $+59.5 \mathrm{Wm}^{-2}$ and $+80.0 \mathrm{Wm}^{-2}$ on April 21 and May 28, respectively. 


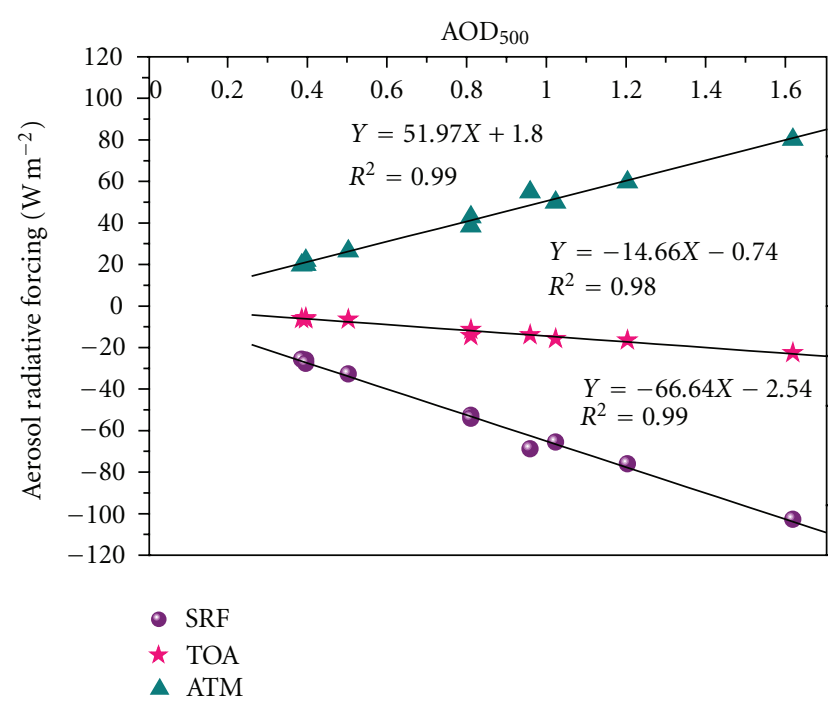

Figure 11: Correlation between $\mathrm{AOD}_{500}$ with $\mathrm{ARF}$ values at TOA, SRF and ATM. The slope of the regressions defines the radiative forcing efficiency.

A plot of $\mathrm{AOD}_{500}$ versus ARF (Figure 11) shows a strong correlation between $\mathrm{AOD}_{500}$ and $\mathrm{ARF}$ values at the surface $\left(R^{2}=0.99\right)$, TOA $\left(R^{2}=0.98\right)$, and within the atmosphere $\left(R^{2}=0.99\right)$. A high degree of correlation between ARF at the surface and AOD provides a good confidence on the calculated values and variation of ARF between dusty and nondusty days indicating that ARF is a strong function of AOD during the study period. The slope of the linear regressions defines the aerosol forcing efficiency that is the rate of forcing per unit AOD and represents the effectiveness of the composite aerosols in perturbing the radiative balance [76]. In the present study, the radiative forcing efficiencies were found to be -14.66 , and -66.64 and $51.97 \mathrm{Wm}^{-2} \mathrm{AOD}^{-1}$ for TOA, surface and atmosphere, respectively. The computed values of radiative forcing efficiency indicate scattering nature of aerosols during the examined days.

Based on previous studies, ARF values at other locations in northern India during premonsoon season indicate significant radiative effects over IGP that are comparable to ARF values over the study region. More specifically, over Kanpur in central IGP, Prasad et al. [36] have reported maximum ARF at the surface and TOA of $-87.5 \mathrm{Wm}^{-2}$ and $-26 \mathrm{Wm}^{-2}$, respectively, during dusty days and corresponding average forcing efficiency of $-46 \mathrm{Wm}^{-2}$ and $-17 \mathrm{Wm}^{-2}$ at the surface and TOA during premonsoon season. Similarly, Gautam et al. [77] reported large negative surface forcing efficiency and mean forcing values of $-70 \mathrm{Wm}^{-2}$ and $-44 \mathrm{Wm}^{-2}$, respectively, during the dust-laden premonsoon season over IGP indicating substantially high aerosol solar absorption effect at surface. Other estimates over Kanpur during the premonsoon season also suggest large negative surface forcing values (greater than $-30 \mathrm{Wm}^{-2}$ ) when transported dust adds to the heavy anthropogenic pollution [78]. On the other hand, Pandithurai et al. [37] performed ARF calculations during premonsoon season of 2006 over Delhi suggesting consistent increase in cooling at surface from $-39 \mathrm{Wm}^{-2}$ in
March to $-99 \mathrm{Wm}^{-2}$ in June, while the atmospheric heating ranged from $27 \mathrm{Wm}^{-2}$ (March) to $123 \mathrm{Wm}^{-2}$ (June) since dust events lead to enhanced heating rates in the lower atmosphere. In addition, values of forcing efficiency at the surface were found to be $-71,-85,-87$, and $-84 \mathrm{Wm}^{-2}$ for March, April, May, and June 2006, respectively [37]. These larger forcing efficiency values compared to present ones indicate more absorbing nature of aerosols over urban Delhi.

The high surface cooling associated to strong atmospheric heating over IGP, in general, and the study region, in particular, during the premonsoon season, may be capable of affecting the atmospheric dynamics. The observed atmospheric heating rate implies that the excess energy in the region is trapped in the atmosphere during the dry season, which can have significant impact on regional climate and monsoon circulation systems $[77,79,80]$.

\section{Conclusions}

The present study examined the effects of dust storms on aerosol optical properties and radiative forcing over Patiala, in the northwestern part of Indo-Gangetic Plains, India, by means of ground-based sun photometer measurements and satellite (MODIS, OMI) remote sensing. The main findings can be summarized as follows.

Significant increase in AOD values up to 1.5 has been observed during the dust storm days, with this increase to be more pronounced at longer wavelengths. This is reflected to the very low values of $\alpha(<0.2)$ and high values of $\beta(>0.6)$ attributed to the abundance of large-sized particles in the atmosphere. The MODIS and OMI observations justify the dust transport over Patiala and IGP, which is particularly intense on 21 April and 28 May, 2010. The OPAC-simulated SSA values during the intense dust-storm days ranged from 0.88 to 0.92 and are wavelength dependent with higher values at longer wavelengths suggesting abundance of coarse dust particles.

A large increase (in absolute values) in ARF was observed during the dust storm period as compared to nondusty days. Daily averaged SRF and TOA ARF values ranged from -75.9 to $-102.6 \mathrm{Wm}^{-2}$ and -16.4 to $-22.6 \mathrm{Wm}^{-2}$, respectively during the intense period of the two dust storms. A high degree of correlation between $\mathrm{AOD}_{500}$ and ARF values at surface $\left(R^{2}=0.99\right)$, TOA $\left(R^{2}=0.98\right)$, and atmosphere $\left(R^{2}=0.99\right)$ was found, indicating that AOD is the main factor that controls ARF during DE over northwestern India. The ARF efficiency was found to be $-14.66,-66.64$, and $51.97 \mathrm{Wm}^{-2}$ at the TOA, surface, and atmosphere, respectively. On the other hand, the atmospheric forcing varied from $+59.5 \mathrm{Wm}^{-2}$ to $+80.0 \mathrm{Wm}^{-2}$ during the day of maximum intensity of the two dust storms, suggesting warming of the lower and middle atmosphere, thus affecting the atmospheric dynamics, and may have significant impact on the regional climate.

\section{Acknowledgments}

The work is supported under ISRO-GBP research project and the authors are grateful to ISRO for financial support. 
The authors would like to thank MODIS and OMI science data teams for processing the data via Giovanni website (http://.gsfc.nasa.gov/). We are also thankful to NOAA Air Resources Laboratory (ARL) for the availability of HYSPLIT model online (http://www.arl.noaa.gov/ready.php). The meteorological data for Patiala Station provided by IMD is highly acknowledged.

\section{References}

[1] R. J. Charlson and J. Heintzenberg, Aerosol Forcing of Climate, John Wiley and Sons, Chichester, UK, 1995.

[2] J. Hansen, M. Sato, and R. Ruedy, "Radiative forcing and climate response," Journal of Geophysical Research, vol. 102, no. D6, pp. 6831-6864, 1997.

[3] S. A. Christopher, J. Wang, Q. Ji, and S. C. Tsay, "Estimation of diurnal shortwave dust aerosol radiative forcing during PRIDE," Journal of Geophysical Research, vol. 108, no. D19, Article ID 8596, 12 pages, 2003.

[4] D. Tanre, J. Haywood, J. Pelon et al., "Measurement and modeling of the Saharan dust radiative impact: overview of the Saharan Dust Experiment (SHADE)," Journal of Geophysical Research, vol. 108, no. D18, Article ID D8574, 2003.

[5] R. A. Duce, "Sources, distributions, and fluxes of mineral aerosols and their relationship to climate," in Aerosol Forcing of Climate, R. Charlson and J. Heintzenberg, Eds., pp. 43-72, Wiley, New York, NY, USA, 1995.

[6] T. Claquin, M. Schulz, Y. Balkanski, and O. Boucher, "Uncertainties in assessing radiative forcing by mineral dust," Tellus B, vol. 50, no. 5, pp. 491-505, 1998.

[7] A. Di Sarra, T. Di Iorio, M. Cacciani, G. Fiocco, and D. Fuà, "Saharan dust profiles measured by lidar at Lampedusa," Journal of Geophysical Research, vol. 106, no. D10, pp. 1033510347, 2001.

[8] J. H. Seinfeld, G. R. Carmichael, R. Arimoto et al., "ACE-ASIA: regional climatic and atmospheric chemical effects of Asian dust and pollution," Bulletin of the American Meteorological Society, vol. 85, no. 3, pp. 367-380, 2004.

[9] S. K. Das and A. Jayaraman, "Role of black carbon in aerosol properties and radiative forcing over western India during premonsoon period," Atmospheric Research, vol. 102, no. 3, pp. 320-334, 2011.

[10] I. Tegen, A. A. Lacis, and I. Fung, "The influence on climate forcing of mineral aerosols from disturbed soils," Nature, vol. 380, no. 6573, pp. 419-422, 1996.

[11] P. Ginoux, M. Chin, I. Tegen et al., "Sources and distributions of dust aerosols simulated with the GOCART model," Journal of Geophysical Research, vol. 106, no. D17, pp. 20255-20273, 2001.

[12] P. Alpert, P. Kishcha, A. Shtivelman, S. O. Krichak, and J. H. Joseph, "Vertical distribution of Saharan dust based on 2.5year model predictions," Atmospheric Research, vol. 70, no. 2, pp. 109-130, 2004.

[13] R. P. Singh, A. K. Prasad, V. K. Kayetha, and M. Kafatos, "Enhancement of oceanic parameters associated with dust storms using satellite data," Journal of Geophysical Research, vol. 113, Article ID C11008, 13 pages, 2008.

[14] P. T. Nastos, N. A. Kampanis, K. N. Giaouzaki, and A. Matzarakis, "Environmental impacts on human health during a Saharan dust episode at Crete Island, Greece," Meteorologische Zeitschrift, vol. 20, no. 5, pp. 517-529, 2011.
[15] C. Moulin, C. E. Lambert, U. Dayan et al., "Satellite climatology of African dust transport in the Mediterranean atmosphere," Journal of Geophysical Research, vol. 103, no. D11, pp. 13137-13144, 1998.

[16] J. M. Prospero, "Long-term measurements of the transport of African mineral dust to the southeastern United States: implications for regional air quality," Journal of Geophysical Research, vol. 104, no. D13, pp. 15917-15927, 1999.

[17] R. Washington, M. Todd, N. J. Middleton, and A. S. Goudie, "Dust-storm source areas determined by the total ozone monitoring spectrometer and surface observations," Annals of the Association of American Geographers, vol. 93, no. 2, pp. 297313, 2003.

[18] H. El-Askary, R. Gautam, R. P. Singh, and M. Kafatos, "Dust storms detection over the Indo-Gangetic basin using multi sensor data," Advances in Space Research, vol. 37, no. 4, pp. 728-733, 2006.

[19] K. V. S. Badarinath, S. K. Kharol, D. G. Kaskaoutis, and H. D. Kambezidis, "Dust storm over Indian region and its impact on the ground reaching solar radiation-a case study using multi-satellite data and ground measurements," Science of Total Environment, vol. 384, pp. 316-332, 2007.

[20] R. Gautam, Z. Liu, R. P. Singh, and N. C. Hsu, "Two contrasting dust-dominant periods over India observed from MODIS and CALIPSO data," Journal of Geophysical Research Letters, vol. 36, no. 6, Article ID L06813, 2009.

[21] D. R. Sikka, "Desert climate and its dynamics," Current Science, vol. 72, no. 1, pp. 35-46, 1997.

[22] D. Ganguly, A. Jayaraman, and H. Gadhavi, "Physical and optical properties of aerosols over an urban location in western India: seasonal variabilities," Journal of Geophysical Research, vol. 111, Article ID D24206, 21 pages, 2006.

[23] S. Kedia and S. Ramachandran, "Seasonal variations in aerosol characteristics over an urban location and a remote site in western India," Atmospheric Environment, vol. 45, no. 12, pp. 2120-2128, 2011.

[24] R. P. Singh, S. Dey, S. N. Tripathi, V. Tare, and B. Holben, "Variability of aerosol parameters over Kanpur, northern India," Journal of Geophysical Research, vol. 109, Article ID D23206, 14 pages, 2004.

[25] S. Dey, S. N. Tripathi, R. P. Singh, and B. N. Holben, "Influence of dust storms on the aerosol optical properties over the IndoGangetic basin," Journal of Geophysical Research, vol. 109, Article ID D20211, 13 pages, 2004.

[26] A. K. Prasad and R. P. Singh, "Changes in aerosol parameters during major dust storm events (2001-2005) over the IndoGangetic basin using AERONET and MODIS data," Journal of Geophysical Research, vol. 112, Article ID D09208, 2007.

[27] A. K. Srivastava, S. N. Tripathi, S. Dey, V. P. Kanawade, and S. Tiwari, "Inferring aerosol types over the Indo-Gangetic basin from ground based sunphotometer measurements," Atmospheric Research, vol. 109-110, pp. 64-75, 2012.

[28] A. P. Mitra and C. Sharma, "Indian aerosols: present status," Chemosphere, vol. 49, no. 9, pp. 1175-1190, 2002.

[29] M. Singh, D. Singh, and P. Pant, "Aerosol characteristics at Patiala during ICARB - 2006," Journal of Earth System Science, vol. 117, no. 1, pp. 407-411, 2008.

[30] M. Sharma, Y. N. V. M. Kiran, and K. K. Shandilya, "Investigations into formation of atmospheric sulfate under high PM10 concentration," Atmospheric Environment, vol. 37, no. 14, pp. 2005-2013, 2003.

[31] D. Ganguly, A. Jayaraman, T. A. Rajesh, and H. Gadhavi, "Wintertime aerosol properties during foggy and nonfoggy days over urban center Delhi and their implications for 
shortwave radiative forcing," Journal of Geophysical Research, vol. 111, Article ID D15217, 15 pages, 2006.

[32] S. Singh, S. Nath, R. Kohli, and R. Singh, "Aerosols over Delhi during pre-monsoon months: characteristics and effects on surface radiation forcing," Geophysical Research Letters, vol. 32, Article ID L13808, 4 pages, 2005.

[33] S. Singh, K. Soni, T. Bano, R. S. Tanwar, S. Nath, and B. C. Arya, "Clear sky direct aerosol radiative forcing variations over mega-city Delhi," Annales Geophysicae, vol. 28, no. 5, pp. 1157-1166, 2010.

[34] A. K. Srivastava, S. Singh, S. Tiwari, and D. S. Bisht, "Contribution of anthropogenic aerosols in direct radiative forcing and atmospheric heating rate over Delhi in the Indo-Gangetic basin," Environmental Science Pollution Research. In press.

[35] P. Hedge, P. Pant, M. Naja, U. C. Dumka, and R. Sagar, "South Asian dust episode in June 2006: aerosol observations in the central Himalayas," Journal of Geophysical Research Letters, vol. 34, Article ID L23802, 2007.

[36] A. K. Prasad, S. Singh, S. S. Chauhan, M. K. Srivastava, R. P. Singh, and R. Singh, "Aerosol radiative forcing over the Indo-Gangetic plains during major dust storms," Atmospheric Environment, vol. 41, no. 29, pp. 6289-6301, 2007.

[37] G. Pandithurai, S. Dipu, K. K. Dani et al., "Aerosol radiative forcing during dust events over New Delhi, India," Journal of Geophysical Research D, vol. 113, Article ID D13209, 13 pages, 2008.

[38] R. P. Guleria, J. C. Kuniyal, P. S. Rawat et al., "The assessment of aerosol optical properties over Mohal in the northwestern Indian Himalayas using satellite and ground-based measurements and an influence of aerosol transport on aerosol radiative forcing," Meteorology and Atmospheric Physics, pp. 117, 2011.

[39] K. V. S. Badarinath, S. K. Kharol, A. R. Sharma, and V. K. Prasad, "Analysis of aerosol and carbon monoxide characteristics over Arabian Sea during crop residue burning period in the Indo-Gangetic Plains using multi-satellite remote sensing datasets," Journal of Atmospheric and Solar-Terrestrial Physics, vol. 71, no. 12, pp. 1267-1276, 2009.

[40] A. R. Sharma, S. K. Kharol, K. V. S. Badarinath, and D. Singh, "Impact of agriculture crop residue burning on atmospheric aerosol loading — a study over Punjab State, India," Annales Geophysicae, vol. 28, no. 2, pp. 367-379, 2010.

[41] M. Morys, F. M. Mims III, S. Hagerup et al., "Design, calibration, and performance of MICROTOPS II handheld ozone monitor and Sun photometer," Journal of Geophysical Research, vol. 106, no. D13, pp. 14573-14582, 2001.

[42] J. N. Porter, M. Miller, C. Pietras, and C. Motell, "Ship-based sun photometer measurements using microtops sun photometers," Journal of Atmospheric and Oceanic Technology, vol. 18, no. 5, pp. 765-774, 2001.

[43] A. Ångström, "The parameters of atmospheric turbidity," Tellus, vol. 16, no. 1, pp. 64-75, 1964.

[44] T. F. Eck, B. N. Holben, J. S. Reid et al., "Wavelength dependence of the optical depth of biomass burning, urban, and desert dust aerosols," Journal of Geophysical Research, vol. 104, no. D24, pp. 31333-31349, 1999.

[45] D. G. Kaskaoutis, M. C. R. Kalapureddy, K. K. Moorthy et al., "eterogeneity in pre-monsoon aerosol types over the Arabian Sea deduced from shipboard measurements of spectral AODs," Atmospheric Chemistry and Physics, vol. 10, no. 10, pp. 4893-4908, 2010.

[46] R. C. Levy, L. A. Remer, S. Mattoo, E. F. Vermote, and Y. J. Kaufman, "Second-generation algorithm for retrieving aerosol properties over land from MODIS spectral reflectance," Journal of Geophysical Research D, vol. 112, Article ID D13211, 21 pages, 2007.

[47] Y. Shi, J. Zhang, J. S. Reid, B. Holben, E. J. Hyer, and C. Curtis, "An analysis of the collection 5 MODIS over-ocean aerosol optical depth product for its implication in aerosol assimilation," Atmospheric Chemistry and Physics, vol. 11, no. 2, pp. 557-565, 2011.

[48] R. C. Levy, L. A. Remer, R. G. Kleidman et al., "Global evaluation of the Collection 5 MODIS dark-target aerosol products over land," Atmospheric Chemistry and Physics Discussions, vol. 10, no. 6, pp. 14815-14873, 2010.

[49] L. A. Remer, Y. J. Kaufman, D. Tanré et al., "The MODIS aerosol algorithm, products, and validation," Journal of the Atmospheric Sciences, vol. 62, no. 4, pp. 947-973, 2005.

[50] O. Torres, P. K. Bhartia, J. R. Herman, Z. Ahmad, and J. Gleason, "Derivation of aerosol properties from satellite measurements of backscattered ultraviolet radiation: theoretical basis," Journal of Geophysical Research, vol. 103, no. D14, pp. 17099-17110, 1998.

[51] D. G. Kaskaoutis, P. T. Nastos, P. G. Kosmopoulos, H. D. Kambezidis, S. K. Kharol, and K. V. S. Badarinath, "The AuraOMI Aerosol Index distribution over Greece," Atmospheric Research, vol. 98, no. 1, pp. 28-39, 2010.

[52] P. F. Levelt, G. H. J. van den Oord, M. R. Dobber et al., "The ozone monitoring instrument," IEEE Transactions on Geoscience and Remote Sensing, vol. 44, no. 5, pp. 1093-1100, 2006.

[53] P. F. Levelt, E. Hilsenrath, G. W. Leppelmeier et al., "Science objectives of the ozone monitoring instrument," IEEE Transactions on Geoscience and Remote Sensing, vol. 44, no. 5, pp. 1199-1208, 2006.

[54] C. Ahn, O. Torres, and P. K. Bhartia, "Comparison of ozone monitoring instrument UV aerosol products with AQUA/Moderate resolution Imaging spectroradiometer and multiangle imaging spectroradiometer observations in 2006," Journal of Geophysical Research D, vol. 113, Article ID D16S27, 13 pages, 2008.

[55] R. R. Draxler and G. D. Rolph, HYSPLIT (Hybrid SingleParticle Lagrangian Integrated Trajectory) Model, NOAA Air Resources Laboratory, Silver Spring, Md, USA, 2003, http:// www.arl.noaa.gov/ready/hysplit4.html.

[56] D. G. Kaskaoutis, P. G. Kosmopoulos, H. D. Kambezidis, and P. T. Nastos, "Identification of different aerosol types over Athens, Greece. The influence of transport," Advances in Meteorology, vol. 2010, Article ID 168346, 12 pages, 2010.

[57] N. J. Middleton, "Dust storms in the Middle East," Journal of Arid Environments, vol. 10, no. 2, pp. 83-96, 1986.

[58] R. Gautam, N. C. Hsu, S. C. Tsay et al., "Accumulation of aerosols over the Indo-Gangetic plains and southern slopes of the Himalayas: distribution, properties and radiative effects during the 2009 pre-monsoon Season," Atmospheric Chemistry and Physics Discussions, vol. 11, no. 5, pp. 15697-15743, 2011.

[59] N. Chinnam, S. Dey, S. N. Tripathi, and M. Sharma, "Dust events in Kanpur, northern India: chemical evidence for source and implications to radiative forcing," Journal of Geophysical Research Letters, vol. 33, no. 8, Article ID L08803, 2006.

[60] K. K. Moorthy, S. S. Babu, S. K. Satheesh, J. Srinivasan, and C. B. S. Dutt, "Dust absorption over the "Great Indian desert" inferred using ground-based and satellite remote sensing," Journal of Geophysical Research, vol. 112, Article ID D09206, 10 pages, 2007. 
[61] S. K. Satheesh and J. Srinivasan, "Enhanced aerosol loading over Arabian Sea during the pre-monsoon season: natural or anthropogenic?" Geophysical Research Letters, vol. 29, no. 18, Article ID 1874, 4 pages, 2002.

[62] F. E. Volz, "Photometer mit Selen-Photoelement zur spektralen Messung der Sonnenstrahlung und zur Bestimmung der Wellenlaengenabhaengigkeit der Dunsttruebung," Archiv für Meteorologie, Geophysik und Bioklimatologie B, vol. 10, pp. 100-131, 1959.

[63] D. G. Kaskaoutis and H. D. Kambezidis, "Comparison of the Ångström parameters retrieval in different spectral ranges with the use of different techniques," Meteorology and Atmospheric Physics, vol. 99, no. 3-4, pp. 233-246, 2008.

[64] D. G. Kaskaoutis, H. D. Kambezidis, N. Hatzianastassiou, P. G, Kosmopoulos, and K. V. S. Badarinath, "Aerosol climatology: dependence of the Ångström exponent on wavelength over four AERONET sites," Atmospheric Chemistry and Physics Discussions, vol. 7, no. 3, pp. 7347-7397, 2007.

[65] N. Hatzianastassiou, C. Matsoukas, A. Fotiadi et al., "Global distribution of Earth's surface shortwave radiation budget," Atmospheric Chemistry and Physics, vol. 5, no. 10, pp. 28472867, 2005.

[66] S. K. Satheesh, V. Vinoj, and K. K. Moorthy, "Radiative effects of aerosols at an urban location in southern India: observations versus model," Atmospheric Environment, vol. 44, no. 39, pp. 5295-5304, 2010.

[67] M. Hess, P. Koepke, and I. Schult, "Optical properties of aerosols and clouds: the software package OPAC," Bulletin of the American Meteorological Society, vol. 79, no. 5, pp. 831844, 1998.

[68] S. S. Babu, S. K. Satheesh, and K. K. Moorthy, "Aerosol radiative forcing due to enhanced black carbon at an urban site in India," Geophysical Research Letters, vol. 29, no. 18, Article ID 1880, 4 pages, 2002.

[69] S. K. Satheesh, V. Ramanathan, B. N. Holben et al., "Physical, chemical and radiative properties of Indian ocean aerosols," Journal of Geophysical Research, vol. 107, no. D23, Article ID 4725, 13 pages, 2002.

[70] S. K. Satheesh, J. Srinivasan, and K. K. Moorthy, "Spatial and temporal heterogeneity in aerosol properties and radiative forcing over Bay of Bengal: sources and role of aerosol transport," Journal of Geophysical Research, vol. 111, Article ID D08202, 10 pages, 2006.

[71] K. Soni, S. Singh, T. Bano, R. S. Tanwar, S. Nath, and B. C. Arya, "Variations in single scattering albedo and Angstrom absorption exponent during different seasons at Delhi, India," Atmospheric Environment, vol. 44, no. 35, pp. 4355-4363, 2010.

[72] S. S. Babu, K. K. Moorthy, and S. K. Satheesh, “Temporal heterogeneity in aerosol characteristics and the resulting radiative impacts at a tropical coastal station. Part 2: direct short wave radiative forcing," Annales Geophysicae, vol. 25, no. 11, pp. 2309-2320, 2007.

[73] P. Ricchiazzi, S. Yang, C. Gautier, and D. Sowle, "SBDART: a research and teaching software tool for plane-parallel radiative transfer in the Earth's atmosphere," Bulletin of the American Meteorological Society, vol. 79, no. 10, pp. 2101-2114, 1998.

[74] K. K. Moorthy, S. S. Babu, and S. K. Satheesh, "Aerosol characteristics and radiative impacts over the Arabian Sea during the intermonsoon season: results from ARMEX field campaign," Journal of the Atmospheric Sciences, vol. 62, no. 1, pp. 192-206, 2005.
[75] P. Pant, P. Hedge, U. C. Dumka et al., "Aerosol characteristics at high altitude location in central Himalayas: optical properties and radiative forcing," Journal of Geophysical Research, vol. 111, Article ID D17206, 2006.

[76] D. Santos, M. J. Costa, and A. M. Silva, "Direct SW aerosol radiative forcing over Portugal," Atmospheric Chemistry and Physics, vol. 8, no. 19, pp. 5771-5786, 2008.

[77] R. Gautam, N. C. Hsu, and K. M. Lau, "Premonsoon aerosol characterization and radiative effects over the Indo-Gangetic plains: implications for regional climate warming," Journal of Geophysical Research D, vol. 115, no. 17, Article ID D17208, 2010.

[78] S. Dey and S. N. Tripathi, "Aerosol direct radiative effects over Kanpur in the Indo-Gangetic basin, northern India: longterm (2001-2005) observations and implications to regional climate," Journal of Geophysical Research, vol. 113, Article ID D04212, 20 pages, 2008.

[79] V. Ramanathan, P. J. Crutzen, J. T. Kiehl, and D. Rosenfeld, "Atmosphere: aerosols, climate, and the hydrological cycle," Science, vol. 294, no. 5549, pp. 2119-2124, 2001.

[80] V. Ramanathan, M. V. Ramana, G. Roberts et al., "Warming trends in Asia amplified by brown cloud solar absorption," Nature, vol. 448, no. 7153, pp. 575-578, 2007. 

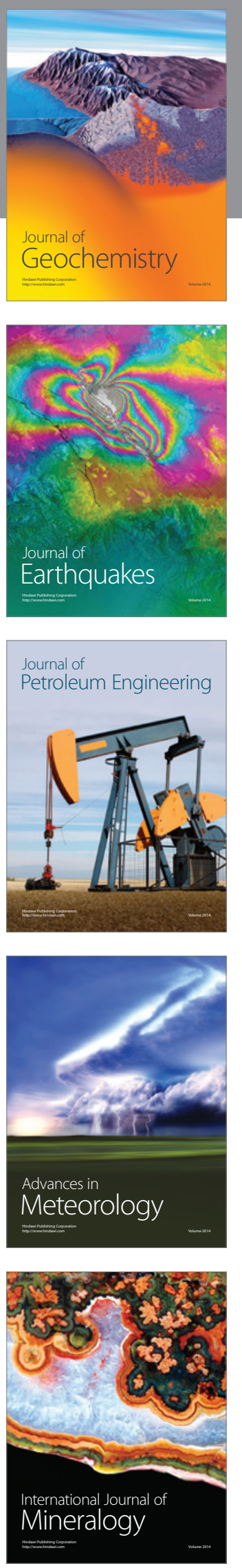
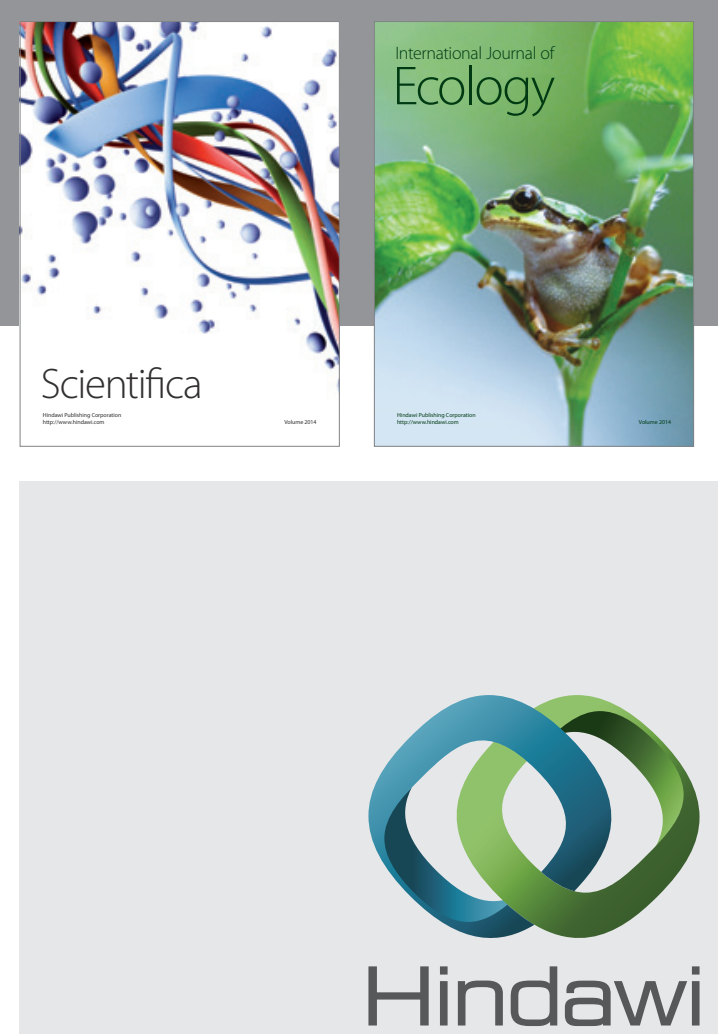

Submit your manuscripts at http://www.hindawi.com
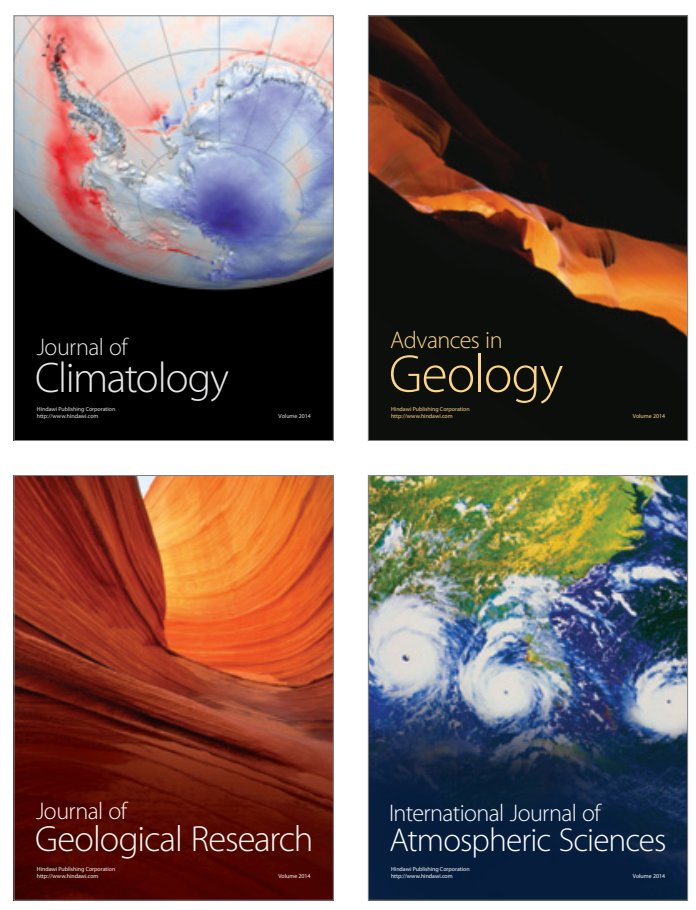
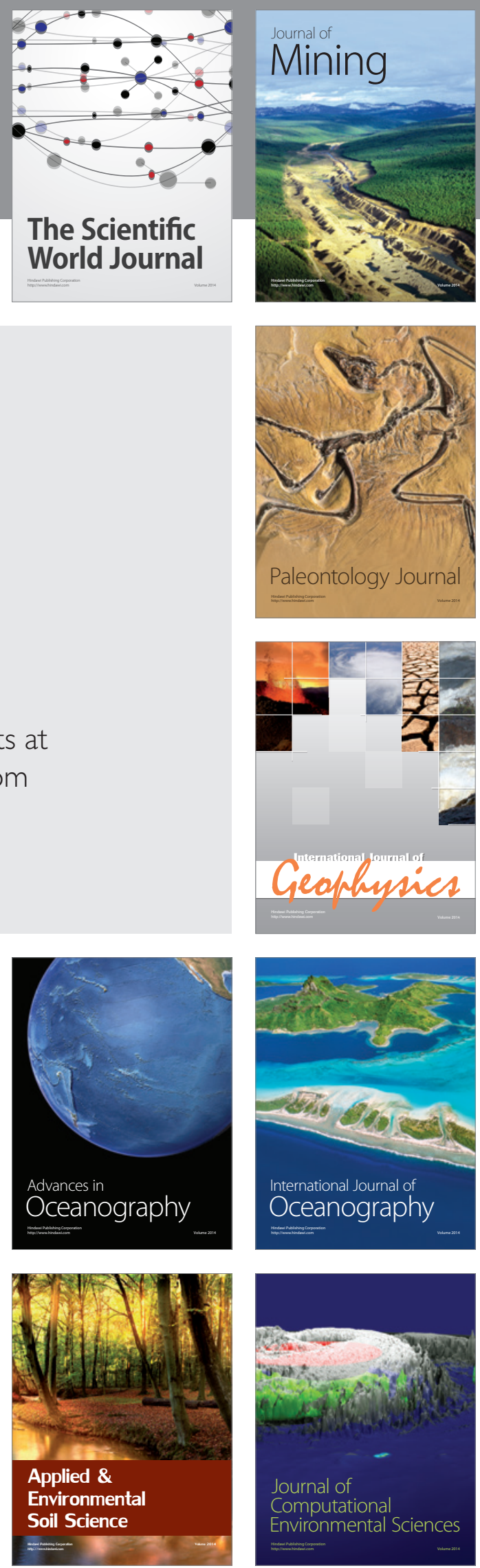